http://dx.doi.org/10.5597/lajam00166

\title{
UPDATE ON THE FRESHWATER DISTRIBUTION OF SOTALIA in Colombia, Ecuador, Peru, Venezuela and Suriname
}

\author{
Catalina Gómez-Salazar ${ }^{1,2,}$, Marcela Portocarrero-Aya ${ }^{1,3}$, Fernando Trujillo ${ }^{1}$, \\ Susana Caballero ${ }^{4}$, Jaime Bolaños-Jiménez ${ }^{5}$, Víctor Utreras ${ }^{6}$, Tamara McGuire ${ }^{7}$, \\ Arnaldo Ferrer-Pérez ${ }^{8}$, Monique Pool ${ }^{9}$ and Enzo Aliaga-Rossel ${ }^{10,11}$
}

\begin{abstract}
Sotalia dolphins inhabit the Amazon and Orinoco River basins and the Caribbean and Atlantic coasts in Central and South America (Flores and da Silva, 2009). The tucuxi (Sotalia fluviatilis) inhabits the Amazon basin, while the Guiana dolphin (Sotalia guianensis) inhabits the Caribbean and Atlantic coasts of South America, including some estuarine and riverine areas (Borobia et al., 1991). To date, it is unknown what species inhabits the Orinoco basin (Caballero et al., 2007).
\end{abstract}

Most of the information on the freshwater distribution of cetaceans that inhabit these areas is derived from incidental sightings and from small-scale, localized surveys. Knowledge of the distribution of wildlife species is necessary to evaluate their conservation status and to monitor possible changes overtime. Sotalia fluviatilis is currently listed by the International Union for Conservation of Nature (IUCN) as Data Deficient (Reeves et al., 2008 ${ }^{12}$ ) and the status of Sotalia guianensis has yet to be established. Sotalia is listed in Appendix I of Convention on International Trade in Endangered Species of Wild Fauna and Flora (CITES). Locally, S. fluviatilis is listed as Vulnerable in Colombia (Trujillo et al., 2006), Endangered in Ecuador (Tirira, 2001; Utreras et al., 2001), Data Deficient in Brazil (Ibama, 1997), and Data Deficient in Peru (E. Aliaga-Rossel, pers. comm.). S. guianensis is listed as Vulnerable in Venezuela (Bolaños-Jiménez et al., 2008) and its status in Suriname has yet to be established. An update on the distribution of Sotalia would improve information useful to the IUCN to list the species into categories of threat and to recommend actions for their conservation (IUCN, 2010).

Our goal in this paper is to review and update the current distribution of Sotalia dolphins that inhabit freshwater in Colombia, Ecuador and Peru, as well as freshwater and estuarine areas in Venezuela and Suriname. This review and update is based on previous research and on information from recent surveys conducted in selected rivers across the Amazon and Orinoco River basins, and in estuarine areas of Suriname. This paper is part of an initiative to establish a network of Freshwater Protected Areas (FWPAs), specifically involving researchers, governments and local communities into the South American River Dolphin Protected Area Network (SARDPAN), whose goal is to investigate the ecological integrity of freshwaters for the conservation of river dolphins in the Amazon and Orinoco River basins in South America (Portocarrero-Aya et al., 200913; 2010).

\section{Historical Distribution Records}

We summarize first historical published information regarding the distribution of Sotalia in riverine and estuarine habitat. S. fluviatilis is distributed in many rivers and tributaries of the Amazon River basin in Brazil, Colombia, Ecuador and Peru at an elevation ranging from 0-300m above sea level (Borobia et al., 1991; da Silva and Best, 1996; Caballero et al., 2007). In the Orinoco River basin, Sotalia sp. is distributed in the middle and lower Orinoco River and in the estuaries and lower reaches of many other rivers flowing into the Atlantic Ocean (Borobia et al., 1991; da Silva and Best, 1994; 1996; Bolaños-Jiménez et al., 2008). Although Bolaños-Jiménez et al. (2008) included Sotalia from the lower and middle Orinoco in their review under the specific name of $S$. guianensis, in the present paper we

\footnotetext{
${ }^{1}$ Fundación Omacha, Calle 86A No. 23 - 38, Bogotá, Colombia

${ }^{2}$ Dalhousie University, Biology Department, Halifax, Nova Scotia, B3H4J1, Canada

${ }^{3}$ Hull International Fisheries Institute, The University of Hull, Hull, HU6 7RX, UK

${ }^{4}$ Laboratorio de Ecología Molecular de Vertebrados Acuáticos, Departamento de Ciencias Biológicas, Universidad de los Andes, Carrera 1 No. 18A-10, Bogotá, Colombia

${ }^{5}$ Sociedad Ecológica Venezolana Vida Marina, A.P. 162, Cagua, Estado Aragua, Venezuela 2122

${ }^{6}$ Wildlife Conservation Society, Ecuador Program, Eloy Alfaro N 37 - 224 y Coremo, P.O. Box 17-21-168, Quito, Ecuador

${ }^{7}$ LGL Alaska Research Associates, Anchorage, 1101 E 76th Ave., Suite B, Alaska 99518, USA

${ }^{8}$ Fundación La Salle, Avenida Boyacá (Cota Mil) con Maripérez, Caracas, Venezuela

${ }^{9}$ The Green Heritage Fund Suriname and the Dolphin Programme in the Suriname River, Hofstraat 104B, Paramaribo, Suriname

${ }^{10}$ University of Hawaii, EECB Program, Honolulu, HI, USA

${ }^{11}$ Instituto de Ecología-UMSA, Campus Universitario de CotaCota s/n. La Paz, Bolivia

* Corresponding author, e-mail: gomezcatalina@gmail.com, catalina@dal.ca

${ }^{12}$ Reeves, R.R., Crespo, E.A., Dans, S.L., Jefferson, T.A., Karczmarski, L., Laidre, K., O'Corry-Crowe, G., Pedraza, S., Rojas-Bracho, L., Secchi, E.R., Slooten, E., Smith, B.D., WAng, J.Y. and Zhou, K. 2008. Sotalia fluviatilis. IUCN 2010. IUCN Red List of Threatened Species. Version 2010.1. Available at <http:/ / www.iucnredlist.org>. Consulted on 1 May 2010.

${ }^{13}$ Portocarrero-Aya, M., Hoyt, E., Wood, A. And Gomez-Salazar, C. (2009) Building a network of freshwater protected areas (FWPAs) critical to river dolphins conservation. In Proceedings, 1st International Conference on Marine Mammal Protected Areas. 30 March - 3 April 2009. Maui, Hawaii, USA.
} 
refer to these populations as Sotalia sp., on the basis of taxonomic uncertainty (e.g. Cunha et al., 2005; Caballero et al., 2007; Bolaños-Jiménez et al., 2008). S. guianensis is distributed along the Caribbean and Atlantic coasts of South America from Nicaragua to Southern Brazil, including some estuarine and freshwater areas of Venezuela and Suriname (e.g. Borobia et al., 1991; Caballero et al., 2007). In this study we would only refer to the populations of S. guianensis in Suriname that inhabit riverine and estuarine areas.

Colombia - The first records of S. fluviatilis were from the Colombian upper Amazon, close to the city of Leticia (Layne, 1958). S. fluviatilis is also distributed in the Caquetá River, downstream from the Córdoba rapids (Trujillo, 1995; Galindo, 1997; Trujillo et al., 2006), in the Putumayo and Apaporis river, and in the Amazon River in adjacent areas such as Loreto-Yacu, El Correo and Tarapoto Lakes and the Amacayacu and Atacuari tributaries (Obregón et al., 1988; Borobia et al., 1991; Beltrán and Trujillo, 1992²; Trujillo, 1992; 1994; 1997; 2000; Vidal et al., 1997). In the Apaporis River, S. fluviatilis is limited by the Estrella and Puerco rapids (F. Trujillo, pers. obs.). There are no corroborated records of Sotalia sp. in the Colombian Orinoco. A cranium of Sotalia sp. was collected in the town of Amanavén in the middle Colombian Orinoco basin about 15 years ago; however, it is more likely that the cranium was brought from another area where records of Sotalia have been corroborated (F. Trujillo, pers. comm.). In addition, locals from the Colombian city of Puerto Carreño have reported the presence of a small dolphin in the Orinoco River, with all the characteristics of Sotalia but this has not been verified (F. Trujillo, pers. comm.).

Ecuador - S. fluviatilis in the Ecuadorian Amazon have been recorded in the Napo, Pastaza, Bobonaza and Lagartococha Rivers (Borobia et al., 1991; da Silva and Best, 1996; Utreras, 1996; 2001, May-Collado and Wartzok, 2010 this volume), and also in the Cuyabeno River, close to the confluence with the Aguarico River (Herman et al., 1996). A recent review included records from the Putumayo, Guepí, Panayacu, Tiputini, Yasuní, Morona, Mangosiza, Cushuimi, Cangaime, Makuma and Wichimi rivers (Zapata-Ríos and Utreras, 2004; Utreras et al., 2010).

Peru - The first records of $S$. fluviatilis, dating from the 1970s, were from the Amazon River near Iquitos (Kasuya and Kajihara, 1974) and later from the Ucayali, Putumayo and Tigre Rivers (Carvalho, 1961; Grimwood, 1969; Borobia et al., 1991; da Silva et al., 1994; Sokolov et al., 1996). Long term research has been mainly focused in the Pacaya-Samiria National Reserve (Samiria River) (Leatherwood, 1996; Henningsen, 1998; Zuñiga, 1999; Leatherwood et al., 2000; McGuire, 2002; McGuire and
Aliaga-Rossel, 2007; McGuire and Henningsen, 2007; McGuire, 2010 this volume), including the Samiria, Pucate, and Pacaya Rivers, and their associated oxbow lakes and tributaries, as well as the stretch of the Marañon River between the city of Iquitos and the confluence with the Samiria River.

Venezuela - The first records of Sotalia dolphins in freshwater were from $130 \mathrm{~km}$ above the mouth of the Orinoco River in 1800 (von Humboldt, 1852; Hershkovitz, 1963). Subsequently, Osgood (1912) and Pilleri and Pilleri (1982) confirmed the occurrence of Sotalia sp. in that region. Sotalia have been seen in the river mouth of the Orinoco (Linares, 1998; Romero et al., 2001; Linares and Rivas, 2004), in the rivers that flow into the Atlantic Ocean (Borobia et al., 1991; da Silva and Best, 1994) and across the Orinoco River to the Parguaza rapids (fast-flowing waters) (Boher et al., 1995; Bolaños-Jiménez et al., 2008). In the middle Orinoco, Sotalia makes incursions into the Parguaza and Cinaruco Rivers, 1-3km upriver (A. Ferrer-Pérez, pers. obs.).

Suriname - S. guianensis in freshwater were first recorded in the locality of the Marowijne River and in the lower parts of main rivers (Hershkovitz, 1963). Also, S. guianensis were recorded along the Suriname River, being common near the city of Paramaribo (located $\sim 23 \mathrm{~km}$ from the river mouth) and were recorded as far up river in the localities of Domburg and Paranam $(\sim 39 \mathrm{~km}$ and $\sim 58 \mathrm{~km}$ from the river mouth, respectively) (Husson 1978 in da Silva and Best, 1996).

\section{ReCEnT Sightings}

We now summarize recent sightings obtained from surveys conducted since May 2006 in large rivers of the Amazon and Orinoco River basins in Colombia, Ecuador, Peru, Bolivia and Venezuela (Gómez-Salazar et al., 200915, 2011). Six surveys were conducted in different rivers of the Amazon basin (Figure 1). In Peru, surveys were conducted throughout the Samiria, Ucayali and Marañón Rivers, in the vicinity of the city of Iquitos. The most upriver record of Sotalia in the Ucayali River was from its confluence with the Marañon River, $160 \mathrm{~km}$ upriver. In Colombia, surveys were conducted along the Amazon River, including the Loreto-Yacu and Atacuari Rivers and the lakes of Tarapoto, El Correo (Colombia) and Caballo Cocha (Peru). The surveys included the Javari River, a tributary of the Amazon River along the border of Peru and Brazil. S. fluviatilis dolphins were seen throughout all of the surveyed Peruvian and Colombian rivers and lakes. In Ecuador, surveys were conducted along the Napo, Aguarico, Cuyabeno, Yasuní and Lagartococha Rivers, but only a few observations of $S$. fluviatilis were recorded

\footnotetext{
${ }^{14}$ Beltrán, S. And Trujillo, F. (1992) Mortalidad incidental y dirigida de Inia geoffrensis y Sotalia fluviatilis en la Amazonía y Orinoquía colombiana. Page 9 in Abstracts, $5^{\text {ta }}$ Reunión de Especialistas en Mamíferos Acuáticos de América del Sur, 28 September - 2 October 1992, Buenos Aires, Argentina.

${ }^{15}$ Gómez-Salazar, C., Trujlllo, F., Portocarrero, M. and Whitehead, H. (2009) Population estimates of river dolphins in the Amazon and Orinoco basins. Page 95 in Abstracts 18th Biennial Conference Biology of Marine Mammals, 11-16 October 2009, Quebec City, Canada.
} 
in the Cuyabeno and Napo Rivers. Two more surveys were conducted in the Mamoré and Itenez Rivers (Bolivian Amazon) but no Sotalia were sighted and there are also no historical records for these rivers (da Silva and Best, 1996).

Three surveys were conducted in the Orinoco River basin (Figure 2). In Venezuela, surveys were conducted in the Orinoco River, starting from the town of Mapire, State of Anzoátegui, going upstream to the city of Puerto Carreño (Colombia) and later starting from the city of Tucupita, State of Delta Amacuro (Venezuela), and ending at the river mouth in the North Atlantic Ocean, across from Trinidad and Tobago. Five channels in this delta were surveyed. Sotalia dolphins were recorded in all surveys upto the Parguaza rapids, $\sim 20 \mathrm{~km}$ away from the border with Colombia $\left(6^{\circ} 41^{\prime} 491^{\prime \prime} \mathrm{N}, 67^{\circ} 6^{\prime} 563^{\prime \prime} \mathrm{W}\right)$ and $\sim 800 \mathrm{~km}$ from the mouth of the Orinoco. The Parguaza rapids do not seem to be a complete natural barrier. In fact, during the rainy season when the water level in the river increases, these rapids almost disappear. In the Colombian Orinoco, surveys were conducted all through the Meta River. Sotalia were not sighted and are not historically reported to occur there.

The current distribution of S. guianensis in Suriname can be described based on the surveys conducted in the Suriname River estuary by the Dolphin Programme of the Green Heritage Fund Suriname. S. guianensis are distributed in the estuary area of the coast of Suriname and they make incursions into the Suriname River up to $\sim 23 \mathrm{~km}$ from the mouth of the river (Paramaribo City).

\section{UPDATED DisTRIBUTION}

Based on the above review of historical and current records, we present an update of the distribution of S. fluviatilis in the Colombian, Ecuadorian and Peruvian Amazon, of Sotalia sp. in the Venezuelan Orinoco, and of S. guianensis in estuarine and riverine areas of Suriname (Figure 3).

Overall, dolphins of the genus Sotalia in freshwater are distributed through most of the Amazon and Orinoco Rivers, some of their main tributaries, and estuaries in the Caribbean and Atlantic coasts in South America. The freshwater distribution of S. fluviatilis and Sotalia sp. in the middle Orinoco is limited by shallow waters, large rocks, waterfalls, small channels and rapids, such as the rapids at the western upper Amazon, and in other areas like the Cordoba rapids in the Caquetá River, the Estrella and Puerco rapids in the Apaporis River (Colombia), and the Parguaza rapids in the middle Orinoco (Venezuela). Thus, Sotalia dolphins do not reach the Bolivian Amazon or the Colombian Orinoco.

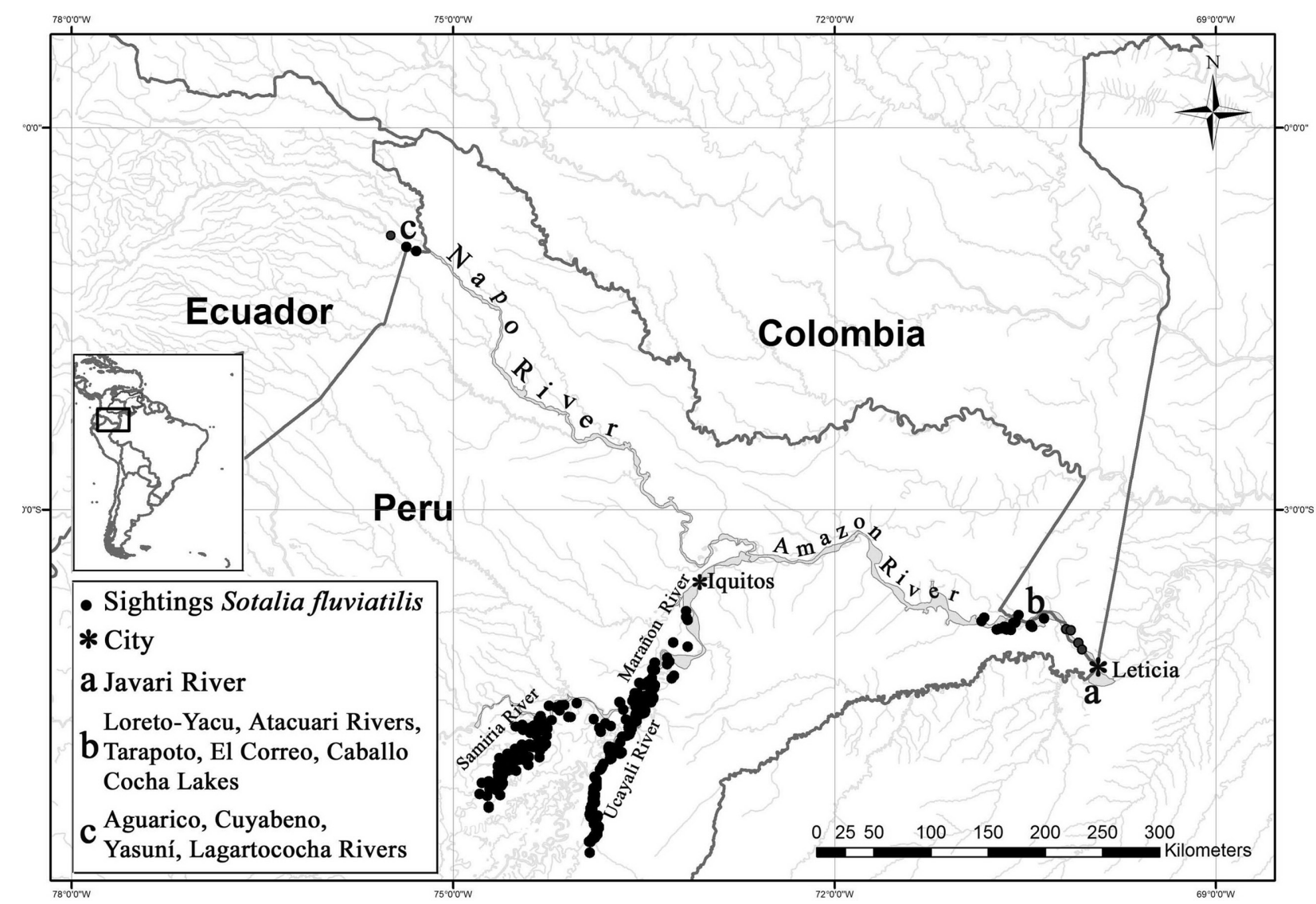

Figure 1. Sightings (2006-2009) records of Sotalia fluviatilis in the Colombian, Ecuadorian and Peruvian Amazon basin. 


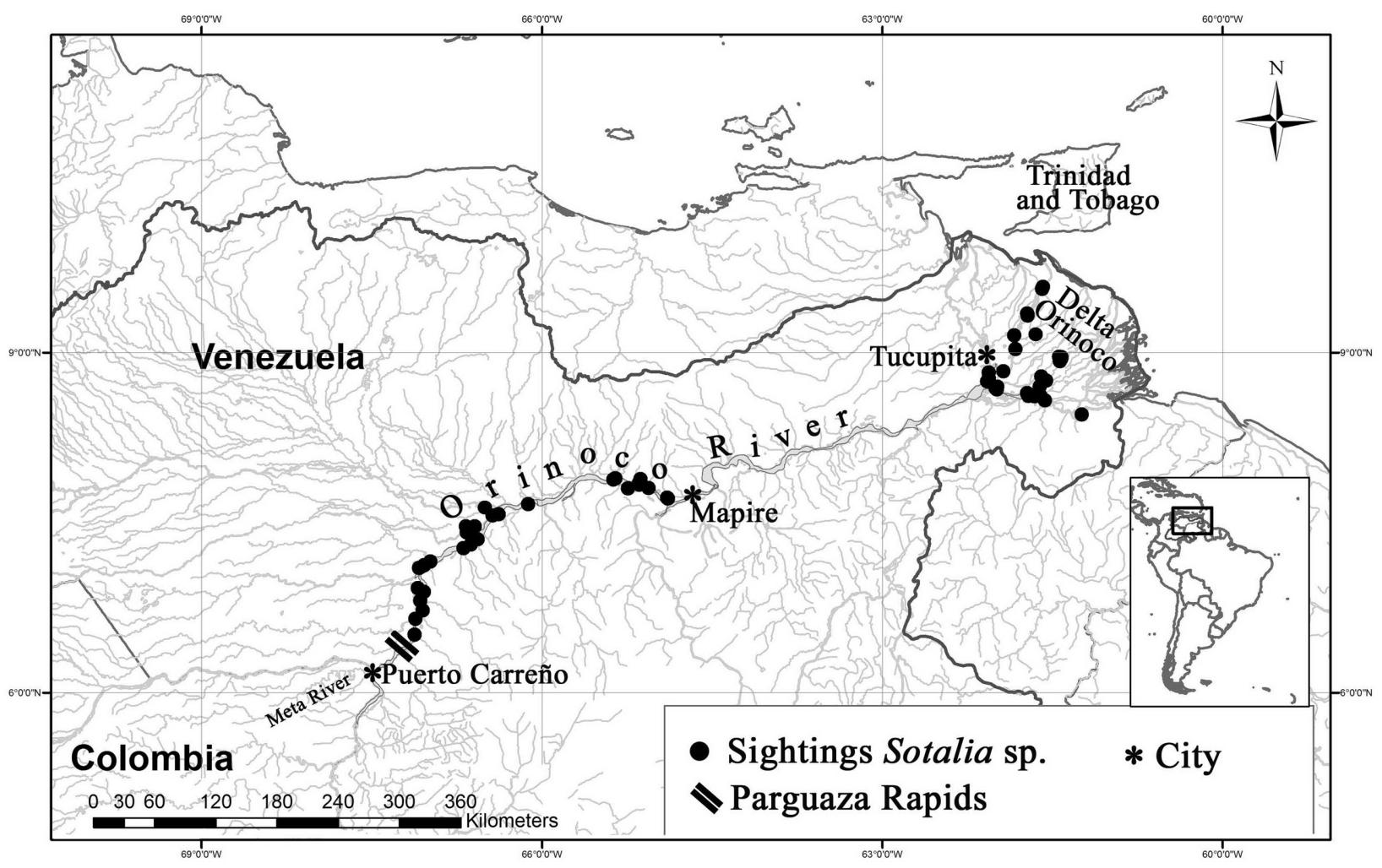

Figure 2. Sightings (2006-2009) of Sotalia sp. in the Venezuelan Orinoco basin.

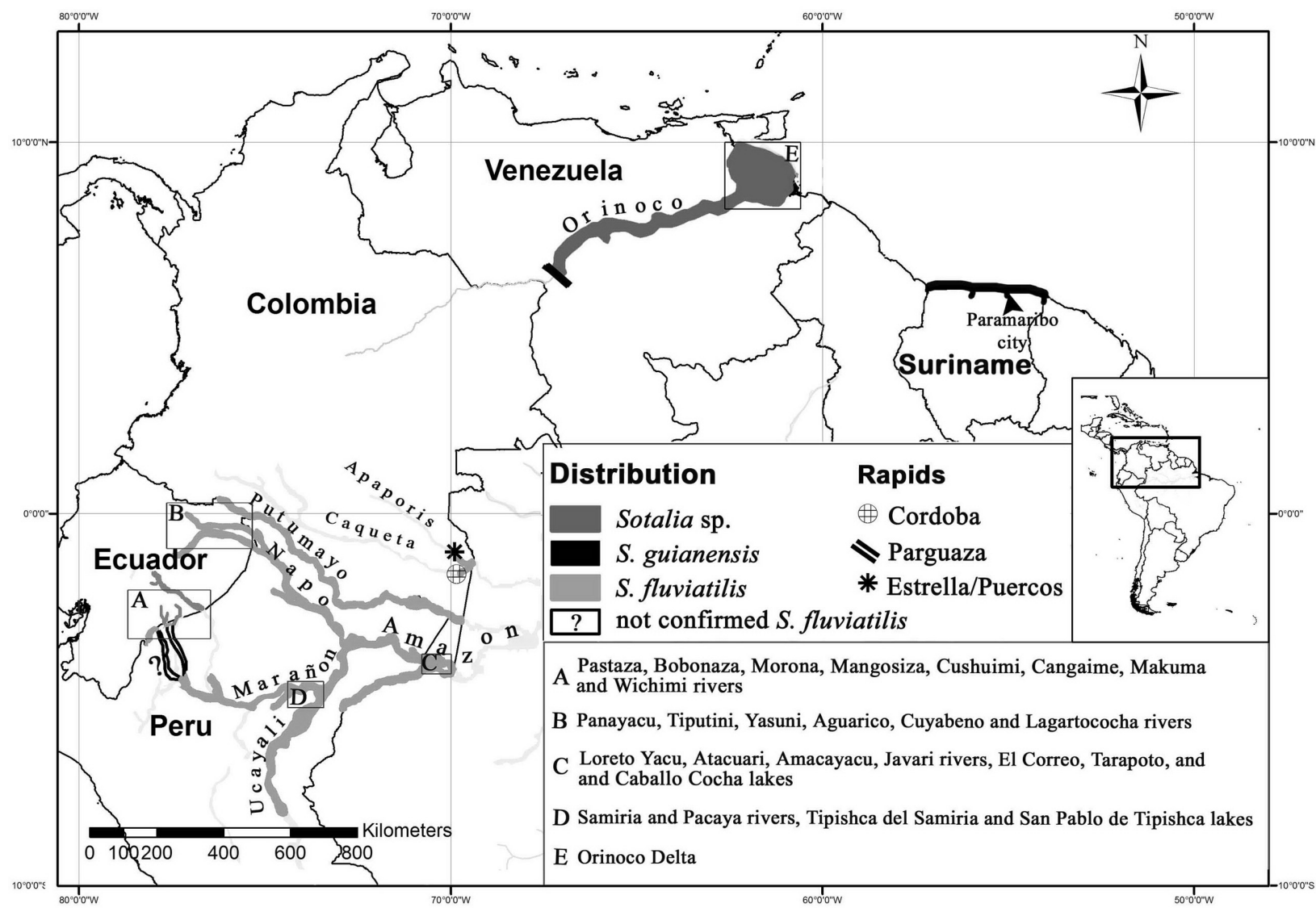

Figure 3. Distribution of Sotalia in the Amazon (Colombia, Ecuador, Peru), Orinoco (Venezuela) and Suriname. 
Amazon River basin - S. fluviatilis is distributed throughout the Ucayali River in Peru, considered the main headwater of the Amazon River, and its confluence with the Marañón River, where the Amazon River begins. S. fluviatilis is also distributed through the Pacaya-Samiria National Reserve, including the Samiria and Pacaya rivers and lakes such as Tipishca del Samiria and San Pablo de Tipishca. There are also records of Sotalia from the Marañon River and from its major tributaries that flow southeasterly from Ecuador: the Pastaza, Morona, Tigre and Napo rivers. The Pastaza River and its tributary, the Bobonaza River, are located in the southern Ecuadorian Amazon. There are some records in the Morona River, parallel to the Pastaza, and several of its tributaries (the Mangosiza, Cushuimi, Cangaime, Makuma and Wichimi rivers). Finally, fewer records of $S$. fluviatilis occur in the Napo River in northern Ecuador, and some of its tributaries such as the Panayacu, the Tiputini, the Yasuní and the Aguarico (which receives the Cuyabeno and Lagarto Cocha Rivers). S. fluviatilis is distributed widely throughout the Amazon River as it flows through the southernmost region of Colombia, receiving the Loreto Yacu (El Correo and Tarapoto Lakes), Atacuari, and Amacayacu tributaries and the Caballo Cocha Lake on the border with Peru and the Javari River on the border of Peru and Brazil. In addition, S. fluviatilis is distributed in southwest Colombia in the Putumayo and Caquetá rivers along the border of Ecuador and Peru. The Putumayo and Caquetá Rivers are main tributaries flowing southeast into the Amazon River in Brazil, where their names change to Içá and Japurá, respectively. The most northwestern records of $S$. fluviatilis in the Amazon River basin are from the Apaporis River, a tributary of the Caquetá River in Colombia.

Orinoco river basin - Sotalia sp. is distributed across the Orinoco River (middle and lower Orinoco basin) in Venezuela, beginning $20 \mathrm{~km}$ from the border of Colombia where the Parguaza rapids are formed, $\sim 815 \mathrm{~km}$ away from the river mouth. In the middle Orinoco basin, Sotalia is distributed $1-3 \mathrm{~km}$ upriver from the Parguaza and Cinaruco Rivers (major tributaries of the Orinoco River). In the lower Orinoco basin, Sotalia (possibly S. guianensis) is found in the river mouth where the Orinoco River forms a wide delta that creates hundreds of tributaries and channels that flow northeast into the North Atlantic Ocean.

In Colombia, Sotalia dolphins are not present in the upper and middle Orinoco basin south of the confluence with the Meta River in waters shared by Colombia and Venezuela. Therefore, the closest Sotalia population is from coastal areas of the Atlantic Ocean (S. guianensis) (Caballero et al., 2007). Sotalia in the Orinoco River were previously thought to be $S$. guianensis making incursions of up to $800 \mathrm{~km}$ upriver (Borobia et al., 1991; Boher et al., 1995; Trujillo et al., 2000; Caballero et al., 2007; BolañosJiménez et al., 2008). However, S. guianensis is significantly larger than S. fluviatilis (Flores and da Silva, 2009) and individuals from the middle Orinoco appear to be smaller than individuals in the delta of the Orinoco. In terms of morphology, individuals observed in the middle Orinoco in Venezuela have a dorsal fin that has a more slender base, more similar to their counterparts in the Amazon basin, than to S. guianensis in the lower Orinoco. Sotalia observed in the lower Orinoco (at about $12-15 \mathrm{~km}$ upriver from the Atlantic Ocean) have a wider dorsal fin base, do not have pink coloration patterns in their flanks, and their eyes appear to be bigger than S. fluviatilis, and more similar to S. guianensis (Figure 4). We suggest that Sotalia dolphins in the Orinoco delta in Venezuela are in fact $S$. guianensis making incursions into the river. Genetic and morphological studies are urgently needed to clarify whether populations in the middle Orinoco of Venezuela are coastal transients making incursions into the river or part of a population that entered via the Amazon to the Orinoco (Borobia et al., 1991; Boher et al., 1995; Cunha et al., 2005; Caballero et al., 2007) or perhaps another subspecies or species altogether.

Differences in the colouration patterns between Sotalia species are interesting and worth investigating. $S$. fluviatilis in the Amazon River basin are light grey and their flanks vary from white to pink that continues through their abdomen (da Silva and Best, 1996; Figure 4). S. guianensis in Suriname are light grayish-blue to dark grey and also have flanks that vary from pink to light pink and white. However, the colour in their flanks appears to continue through to their abdomen. This is in contrast to $S$. fluviatilis in the Amazon, which have a grey streak in between the light coloration of their flanks (Figure 4). Sotalia dolphins in the lower Orinoco do not appear to have any pink in their flanks, and Sotalia dolphins in the middle Orinoco have some pink colour in their flanks.

Suriname - Currently, S. guianensis in the Suriname River has only been recorded up to $\sim 23 \mathrm{~km}$ up from the river mouth (Paramaribo city), much less than the $\sim 58 \mathrm{~km}$ upriver previously recorded by Husson (1978) in da Silva and Best (1996). It is of serious concern that pollution from Paramaribo city may be one of the factors causing this restriction in their movements (M. Pool, pers. comm.). S. guianensis is also recorded in the Commewijne River ( $\sim 38 \mathrm{~km}$ from the Suriname River mouth) and they are occasionally seen up to the locality of Bakkie during the long dry season. In addition, there are reports of S. guianensis in the Corantijn River, the Marowijne and the Coppename Rivers. Overall, $S$. guianensis only swim upriver during the dry season when the saltwater incursion is further upriver and the salinity of the water is high enough.

\section{FINAL REMARKS}

We think that the results of this compilation of available information on the distribution of Sotalia in freshwater of Ecuador, Peru, Colombia, Venezuela and Suriname are useful for identification of some of the major natural barriers for this species, and provide a baseline for monitoring future changes in their geographic range. 

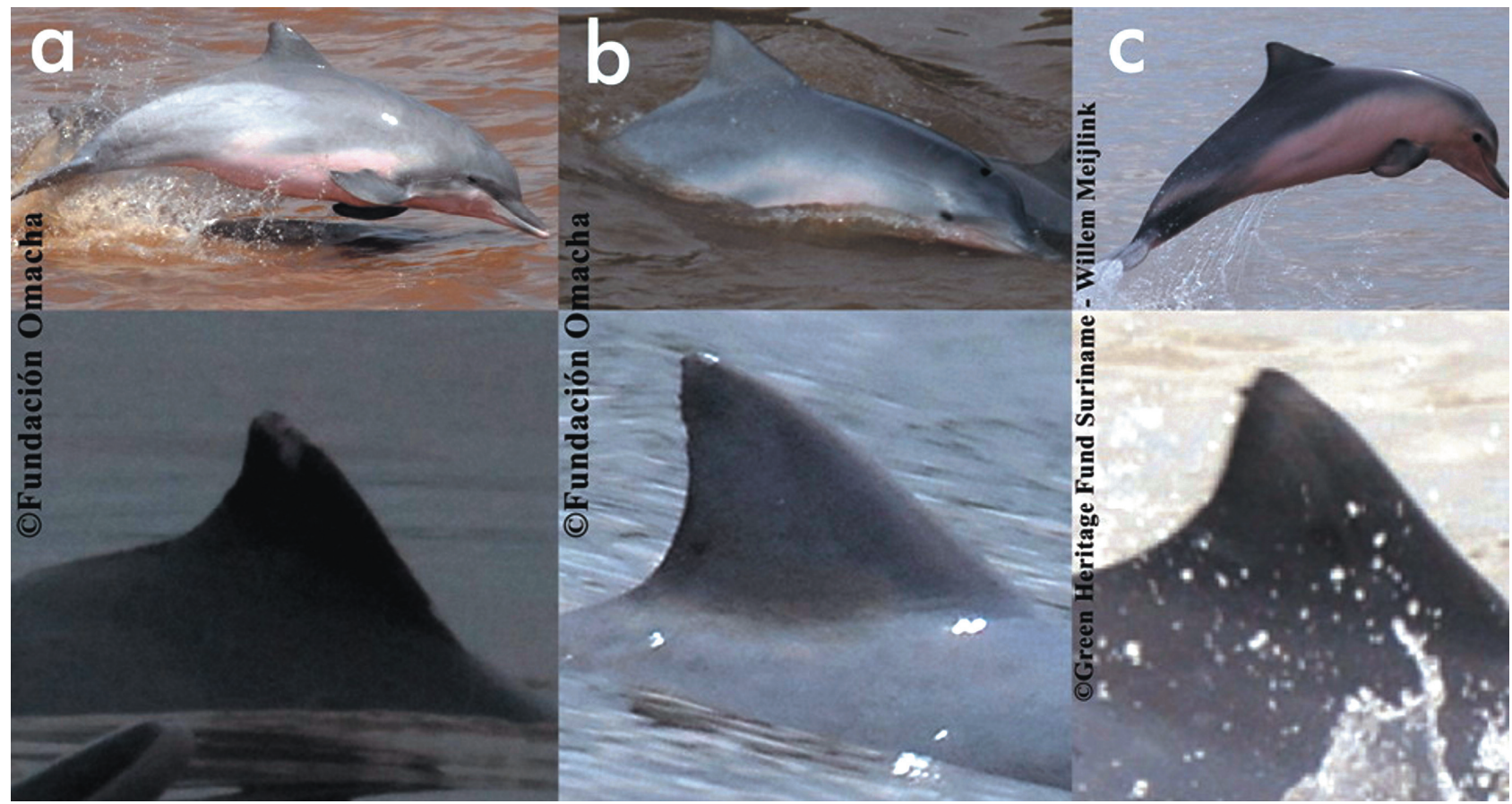

Figure 4. Colouration patterns and dorsal fins of a) Sotalia fluviatilis in the Amazon River (Colombia), b) Sotalia sp. in the delta of the Orinoco River (Venezuela) and c) Sotalia guianensis in the estuary of the Suriname River.

The current distribution of $S$. fluviatilis in the Colombian and Peruvian Amazon basin has not changed compared to historical records. The distribution of S. fluviatilis in the Ecuadorian Amazon needs to be asseessed in more detail. It is of serious concern that the sighting rate was much lower during the recent surveys in the Ecuadorian Amazon compared to other locations studied. Also, the current and increasing effects of water pollution by oil industry, noise pollution, and other forms of habitat degradation in the western areas near the Andean mountains are of concern (Utreras, 2001; Utreras et al., 2010). The distribution of $S$. guianensis in the Suriname River appears to be changing, with dolphins not moving as far upriver as previously reported. Whether these changes are related to high levels of pollution from the city, or other causes, should be investigated. A longterm monitoring program in these areas is highly recommended. In addition, we present current information that suggests that Sotalia in the middle Orinoco River may be more similar, morphologically at least, to $S$. fluviatilis in the Amazon than to S. guianensis in the delta of the Orinoco and along the coast. We recommend genetic studies to identify what species use the middle and lower Orinoco basin in Venezuela.

\section{Acknowledgements}

This study was supported by the Asociacion Faunagua (Bolivia), the Whale and Dolphin Conservation Society (WDCS), Whitley Fund for Nature, Wildlife Conservation Society (WCS), World Wildlife Fund (WWF), Fundación la Salle, Russell E. Train program (WWF), Organization of American States (OAS) Scholarship, National Geographic Society (NGS), Society for Marine Mammalogy Small Grant in Aid of Research, Cetacean Society International (CSI), Humboldt Institute (Colombia), P. Lett Fund, F. Gonzalez del Ministerio del Ambiente (Ecuador), authorities from the Ministerio del Poder Popular para el Ambiente (Venezuela), DEA Delta Amacuro (Venezuela), Guardia Nacional Bolivariana (Venezuela), Fundación la Salle de Ciencias Naturales (Venezuela), Research Center ACOBIA (Association for the Conservation of the Amazon Biodiversity) (Peru), Instituto de Investigaciones de la Amazonía Peruana (IIAP) (Peru) and DIREPRO (Peru), The Dolphin Programme of the Green Heritage Fund (Suriname). We thank P. van Damme (Bolivia), F. Daza (Venezuela), F. Arevalo (Peru), C. Perea (Peru) and N. Martínez (Director de la Reserva de Biosfera del delta del Orinoco) for their support to organize and conduct the surveys. We thank V. Zambrana, A. Villarroel, C. Valverde, G. Tavera, J. Teran, K. Tapayuri, L. Sifontes, L. Sánchez, A. Salinas, L. Ruck, R. Pickles, S. Rudulfo, S. Quevedo, D. Pardo, J.L. Ortiz, C. Ljungquist, C. Navia, S. Jalil, W. Prado, J. Velasquez, O. Herrera, I. Gomez, G. Garrote, N. Gonzalez, A. Gartner, M.C. Diazgranados, E. Davila, N. Castro, C. Contreras, F. Batista, J. Beccerra, P. Aramayo, and all researchers for their work during the surveys. We thank S. Usma, C. Suarez, J. Quesada, F. Marques, X. Galeano, J.M. Fernandez, L. Cuadros, C. Murcia, E. Suárez, D. Caicedo and A.P. Barrios for their technical and logistic support. Many thanks to C. Olavarria, an anonymous reviewer, $\mathrm{S}$. Wong and $\mathrm{H}$. Whitehead for their comments on the manuscript. Thanks to C.L. Barrio-Amorós and 
the Green Heritage Fund Suriname (W. Meijlink) for providing pictures and D.M. Palacios for encouraging us to write this manuscript. We thank E. Hoyt and A. Wood (WDCS) for their guidance and support in the creation of SARDPAN.

\section{References}

Bolaños-Jiménez, J., Pirela, D., Rojas, J. And LeÓn, T. (2008) Bufeo negro, Sotalia guianensis Van Beneden 1863. Page 12 in RodrígueZ, J. P. AND Rojas-SuÁrez, F. (Eds). Libro Rojo de la Fauna de Venezuela. Tercera Edicion. Provita and Shell Venezuela S.A., Caracas, Venezuela.

Boher, S., Bolaños, J. And Cova L. J. (1995) Sobre un avistamiento del delfín estuarino o bufete (Sotalia fluviatilis) en el Orinoco Medio. Acta Científica Venezolana 46:217-218.

Borobia, M., S. SicILIANo, Lodi, L. AND HoeK, W. (1991) Distribution of the South American dolphin Sotalia. Canadian Journal of Zoology 69(4): 1025-1039. http://dx.doi.org/10.1139/z91-148

Caballero, S., Trujillo, F., Vianna, J. A., Barrios-Garrido, H., Montiel, M.G., Beltrán-Pedreros, S., Marmontel, M., Santos, M.C.O., Rossi-SAntos, M., SAntos, F.R. And BAKer, C.S. (2007) Taxonomic status of the genus Sotalia: species level ranking for 'tucuxi' (Sotalia) and 'costero' (Sotalia sp.) dolphins. Marine Mammal Science 23(2): 358-386. http://dx.doi.org/10.1111/ j.1748-7692.2007.00110.x

Cunha, H.A., Da Silva, V.M.F., LaIlson-Brito, J.J., SANTOS, M.C.O., Flores, P.A.C., Martin, A.R., Azevedo, A.F., Fragoso, A.B.L., ZANELATTO, R.C. AND SOlECAVA, A.M. (2005) Riverine and marine ecotypes of Sotalia fluviatilis are different species. Marine Biology 148(2): 449-457. http://dx.doi.org/10.1007/s00227-005-0078-2

DA SIlva, V.M.F. AND Best, R.C. (1994) Tucuxi, Sotalia (Gervais, 1853). Pages 43-69 in Ridgway, S.H. and HarRison R.J. (Eds) Handbook of Marine Mammals. Volume 5. Academic Press, London, UK.

DA Silva, V.M.F. AND Best, R.C. (1996) Sotalia fluviatilis. Mammalian Species 527: 1-7. http:/ / dx.doi.org/10.2307/3504117

Carvalho, C.T. (1961) Esboço mastofaunístico do Território do Rio Branco. Revista Biología Tropical 9: 1-15.

Flores P.A.C. AND DA Silva V.M.F. (2009) Tucuxi and Guiana Dolphin - Sotalia fluviatilis and S. guianensis. Pages 1188-1192 in Perrin, W.F., WÜrsig B., Thewissen, J.G.M. (Eds) Encyclopedia of Marine Mammals. 2nd ed. Academic Press, Amsterdam, Netherlands.

Galindo, A. (1997) Ecología y abundancia de los delfines de río Inia geoffrensis y Sotalia fluviatilis en el río Caquetá, área de influencia de la Pedrera, Colombia. B.Sc. Thesis. Universidad del Valle. Cali, Colombia. 77 pp.

Gómez-Salazar, C., F. Trujillo, M. Portocarrero-Aya, H. Whitehead. 2011. Population, density estimates and conservation of river dolphins (Inia and Sotalia) in the Amazon and Orinoco river basins. Marine Mammal Science. http:/ / dx.doi.org/10.1111/j.1748-7692.2011.00468.x

Grimwood, I.R. (1969) Notes on the distribution and status of some Peruvian mammals. Special Publication. American Committee for International Wildlife Protection and New York Zoological Society 21: 1-86.

Henningsen, T. (1998) Zur verbreitung, habitatwahl und verhaltensökologie der delphine Inia geoffrensis und Sotalia fluviatilis im Oberlauf des Amazonas. Ph.D. Thesis. Zentrum für Marine Tropenökologie. Bremen, Germany. 139 pp.

Herman L.M., Von Fersen, L. and Solangi M. (1996) The bufeo (Inia geoffrensis) in the Rio Lagarto Cocha of the Ecuadorian Amazon. Marine Mammal Science 12(1): 118-125. http:/ / dx.doi.org/10.1111/j.1748-7692.1996.tb00309.x

Hershrovitz, P. 1963. Notes on South American dolphins of the genera Inia, Sotalia and Tursiops. Journal of Mammalogy 44(1): 98-103. http:/ / dx.doi.org/10.2307/1377172

IBAMA. 1997. Mamíferos Aquáticos do Brasil: Plano de Açao. Ministério do Meio Ambiente, dos Recursos Hídricos e da Amazônia Legal. Instituto Brasileiro do Meio Ambiente e dos Recursos Naturais Renováveis. Brasília, Brasil. 79 pp.

IUCN Standards And Petitions Subcommittee. 2010. Guidelines for Using the IUCN Red List Categories and Criteria. Version 8.1. Prepared by the Standards and Petitions Subcommittee in March 2010. [Available from <http://intranet.iucn.org/ webfiles/doc/SSC/RedList/RedListGuidelines.pdf>].

KasuYa, T. AND KaJIHARA, T. (1974) Ecology of dolphins in the Amazon and Orinoco systems. Report of the Scientific Expedition on the La Plata and Amazon Dolphins, University of Tokyo. Expedition on River Dolphins: 7-11.

LAYNE, J. (1958) Observations on freshwater dolphins in the upper Amazon. Journal of Mammalogy 39(1): 1-22. http:/ / dx.doi.org/ $10.2307 / 1376605$

LeATHERWOOD, S. (1996) Distributional ecology and conservation status of river dolphins (Inia geoffrensis and Sotalia fluviatilis) in portions of the Peruvian Amazon. Ph.D Thesis. Texas A\&M University. Galveston, TX, USA. 233 pp.

Leatherwood, S., Reeves, R.R., Wursig, B. ANd SHeArn, D. (2000) Habitat preferences of river dolphins in the Peruvian Amazon. Pages 131-144 in Reeves, R.R.; Smith B.D. And Kasuya T. (Eds) Occasional Paper of the IUCN Species Survival Commission, No. 23. Biology and Conservation of Freshwater Cetaceans in Asia. IUCN, Gland, Switzerland.

Linares, O. J. (1998) Mamíferos de Venezuela. Sociedad Conservacionista Audubón, Caracas, Venezuela.

Linares, O.J. And Rivas, B. (2004). Mamíferos del Sistema Deltaico (delta del Orinoco-Golfo de Paria) Venezuela. Memoria Fundación La Salle Ciencias Naturales 159-160: 27-104.

MaY-Collado, L.J. AND WARTZOK, D. (2010) Sounds produced by the tucuxi (Sotalia fluviatilis) from the Napo and Aguarico rivers of Ecuador. Latin American Journal of Aquatic Mammals 8(1-2): 131-136. http://dx.doi.org/10.5597/lajam00162

McGuire, T. L. (2002) Distribution and abundance of river dolphins in the Peruvian Amazon. Ph.D. Thesis. Texas A\&M University. College Station, Texas, USA. 254 pp.

McGuire, T.L., And Aliaga-Rossel, E.R. (2007) Seasonality of reproduction in Amazon River dolphins (Inia geoffrensis) in three major river basins of South America. Biotrópica 39(1): 135-139.

McGuire, T. L. AND HenNingsen, T. (2007) Movement patterns and site fidelity of river dolphins (Inia geoffrensis and Sotalia fluviatilis) in the Peruvian Amazon as determined by photo-identification. Aquatic Mammals 33(3): 359-367. http:/ / dx.doi.org/10.1578/ AM.33.3.2007.359 
McGuire, T.L. (2010) Ecology and conservation status of tucuxi (Sotalia fluviatilis) in the Pacaya-Samiria Reserve, Peru. Latin American Journal of Aquatic Mammals 8(1-2): 103-110. http://dx.doi.org/10.5597/lajam00158

Obregón, C., Torres, F. And Trujilo, F. (1988) Colombian dolphins. Whalewatcher 22: 21.

OsGood, W.H. (1912) Mammals from western Venezuela and eastern Colombia. Field Museum Natural History Publications Zoology 10(5): 33-66.

Pilleri, G. and Pilleri, O. (1982) Zoologische Expedition zum Orinoco und Brazo Casiquiare 1981. Bern: Hirnanatomisches Institut der Universität Bern, Schweiz. 154 pp.

Romero, A., Agudo, I., Green, S.M and Notarbartolo di Sciara, G. (2001) Cetaceans of Venezuela: Their Distribution and Conservation Status. NOAA Technical Report NMFS 151, 60 pp. [Available from <http://spo.nwr.noaa.gov/tr151.pdf>].

Portocarrero-Aya, M., Hoyt, E. and Wood, A. 2010. Freshwater Protected Areas and their importance in river dolphin conservation. Pages 159-165 in TRUIILLO, F., CRESPO, E., van Damme, P. and Usma, S. (Eds). The Action Plan for South American River Dolphins 2010-2020. WWF, Fundación Omacha, WDS, WDCS, Solamac. Bogotá, D.C., Colombia.

SOLOKOV V.E. AND YASKIN, V.A. (1996) Distribution, population density, and some behavioral peculiarities of Amazonian dolphins. Pages 284-285 in SoloKov, V.E. (Ed). Amazonski delfin. Nauka, Moscow, Russia.

TiriRa, D. (2001) Libro Rojo de los Mamíferos del Ecuador. SIMBIOE, EcoCiencia, Ministerio del Ambiente, UICN. Quito, Ecuador.

Trujillo, F. (1990) Aspectos ecológicos y etológicos de los delfines Inia geoffrensis (de Blainville, 1817) y Sotalia fluviatilis (Gervais, 1853) en la Amazonía Colombiana. B.Sc. Thesis. Universidad Jorge Tadeo Lozano, Bogotá, Colombia. 70 pp.

Trujillo, F. (1992) Estimación poblacional de las especies dulceacuícolas de delfines Inia geoffrensis y Sotalia fluviatilis en el sistema lacustre de Tarapoto y El Correo, Amazonía Colombiana. Special Report. Vol. 49. Centro de Investigaciones Científicas. Universidad Jorge Tadeo Lozano, Bogotá, Colombia.

TrujILlo, F. (1994) The use of photo-identification to study the Amazon River Dolphin, Inia geoffrensis, in the Colombian Amazon. Marine Mammal Science 10(3): 348-353. http://dx.doi.org/ 10.1111/j.1748-7692.1994.tb00489.x

TrujiLlo, F. (1997) The development of a research methodology to study the behaviour and ecology of the freshwater dolphins Inia geoffrensis and Sotalia fluviatilis in the Colombian Amazon. M.Sc. Thesis. University of Greenwich. London, UK. 125 pp.

Trujillo, F. (1995) Aspectos del comportamiento y la distribución de Inia geoffrensis y Sotalia fluviatilis en el rio Caquetá, Colombia. Special Report. Vol. 71. Centro de Investigaciones Científicas, Universidad Jorge Tadeo Lozano. Bogotá, Colombia.

Trujillo F. (2000). Habitat use and social behaviour of the freshwater dolphin Inia geoffrensis (de Blainville 1817) in the Amazon and Orinoco basins. Ph.D. Thesis. Aberdeen University. Scotland. 157 pp.

Trujillo, F., Diazgranados, M.C., Galindo, A and L. Fuentes, (2006). Delfín gris Sotalia fluviatilis. Pages 273-278 in RoDrIGUEZ-
M.J.V., Alberico, M., Trujillo, F. And Jorgenson, J. (Eds) (2006). Libro Rojo de los Mamíferos de Colombia. Serie Libros Rojos de Especies Amenazadas de Colombia. Conservación Internacional and Ministerios de Ambiente, Vivienda y Desarrollo Territorial. Bogota, Colombia.

UTRERAS, V. (1996) Estimación de la abundancia, aspectos ecológicos y etológicos del delfín Amazónico Inia geoffrensis geoffrensis (Cetacea: Iniidae) en el Río Lagartococha, Amazonía Ecuatoriana. B.Sc. Thesis. Pontificia Universidad Católica del Ecuador. Quito, Ecuador.

Utreras, V. (2001) Visión general de los mamíferos acuáticos en el Ecuador, con énfasis en el Parque Nacional Yasuní. Pages 157-164 in Jorgenson, J.P. ANd Coello-Rodríguez, M. (Eds) Conservación y desarrollo sostenible del Parque Nacional Yasuní y su área de influencia. Memorias del Seminario-Taller 2001. Ministerio del Ambiente/UNESCO/Wildlife Conservation Society, Editorial Simbioe, Quito.

Utreras, V., Suarez, E. AND Jalil, S. (2010) Inia geoffrensis geoffrensis and Sotalia fluviatilis: a brief review of the ecology and conservation status of river dolphins in the Ecuadorian Amazon in Trujillo, F., Crespo, E., van Damme, P And Usma, J.S (Eds) The Action Plan for South American river dolphins 20102020. WWF, Fundación Omacha, WDS, WDCS, SOLAMAC. Bogotá, D.C., Colombia.

Vidal O., Barlow, J., Hurtado, L., Torre, J., Cendon, P. and Ojeda, Z. (1997) Distribution and abundance of the Amazon River Dolphin (Inia geoffrensis) and the Tucuxi (Sotalia fluviatilis) in the upper Amazon River. Marine Mammal Science 13(3) 427:445. http://dx.doi.org/10.1111/j.1748-7692.1997.tb00650.x

von Humboldt, A. (1852). Personal narrative of travels to the equinoctial regions of America during the years 1799-1804. Henry G. Bohn, London, 3 vols. (translated by T. Ross).

Zapata-Ríos, G. and Utreras, V. (2004) Notes on the distribution of tucuxi, Sotalia fluviatilis (Cetacea: Delphinidae), in Ecuadorian Amazonia. Latin American Journal of Aquatic Mammals 3(1): 85-87. http://dx.doi.org/10.5597/lajam00054

ZuÑIGA, E. L. 1999. Seasonal distribution of freshwater dolphins in Tipishca del Samiria, Peru. M.Sc. Thesis. Texas A\&M University. College Station, Texas, USA. 126 pp.

Received on 25 May 2010. Accepted on 21 November 2010. Managed by Marcos Santos. 